918

\title{
狭隘環境内で作業可能な伸縮駆動機構を有するレスキューロボットの開発
}

\section{Development of Rescue Robot with Expandable Side Crawler}

\author{
○正 古野 誠治・北九州高専
}

Seiji FURUNO

Kitakyushu National College of Technology
中井 瑞貴・北九州高専

Mizuki NAKAI

Kitakyushu National College of Technology
正 平野 剛・近畿大学

Go HIRANO

Kinki University

Key Words: Rescue Robot, Expandable Side Crawler, Narrow Environment,

\section{1. はじめに}

地震や台風などで建物が倒壊した被災現場では，瓦礫が積 み重なり, 人が入れない狭い場所が数多く存在するため, 瓦 碟内で探査活動を行うロボットが開発されている。例えば, 森らのへビ型ロボット ACM-R3[1] はほふく運動によって推 進するへビと同様な運動により移動を行い, 亀山らのクロー ラ型ロボット KOHGA[2]は複数のクローラ型ロボットを連 結した形状をしている.これらは共に複数ユニットを連結し た構造をしており, 全幅に対して全長が比較的長尺となって いる.これにより狭险環境での活動を可能としているが, 狭 险環境内での方向転換を行う場合, ロボットの全長もしくは 全幅以上の場所が必要であるため, 長尺のロボットでは環境 によっては方向転換が困難になる.

そこで本研究では, 狭险環境で移動できるよう乫起物をな くし, コンパクトかつ高い踏破性を実現する機構を有する探 査用レスキューロボットを開発する.

\section{2. 伸縮駆動機構を有するレスキューロボット}

\section{1 概要}

本研究では Fig.1 に示すような伸縮駆動機構を持つレスキ ューロボットを開発する.4本の独立した駆動用クローラを 平行に配置し, 胴体に固定した 2 本のクローラをセンタクロ 一ラ，両側に取り付けたクローラをサイドクローラとする. 通常時のサイドクローラは Fig.1 のような状態であり，瓦碎 内等の狭险箇所への進入や方向転換が可能である. この状態 で段差を乗り越えられない場合は，Fig.2(a)に示すようにサ イドクローラを伸張（スライド） L，Fig.2(b)に示すように センタクローラとの結合軸周りに回転（フリップ）すること でサイドクーラを腕のように使うことができ, 乗り能力を一 時的に高めることができる. また, 瓦礫が形成する溝の上を 通過する場合にも, サイドクローラを伸ばすことで対応でき る. 以下に, 開発したレスキューロボットの機構, 設計, 八 一ドウェア構成について説明する.

\section{2 スライド機構の設計}

サイドクローラは，センタクローラと同一位置（Fig.1）か ら, センタクローラ前方の回転軸とサイドクローラ後方の回 転軸が一致する位置（Fig.2(a)）までスライドできるものと する.つまり本ロボットのホイールベース長だけスライド可 能とする.またサイドクローラは, ロボット胴体およびセン タクローラに対してフリップ軸のみで結合されており，この 軸がスライド機構との結合点となる。したがって，この軸お よびスライド機構には, サイドクローラの自重によるモーメ ントおよびロボットの運動時の衝撃力が加わる. そこで, こ れらを考慮しスライド機構としてリニアガイドを使用する. 駆動には台形ネジを用い, Fig.3 に示すようにセンタクロー ラ側に取り付ける。

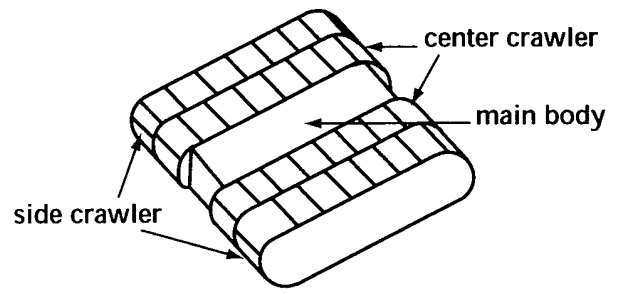

Fig.1 Rescue robot with expandable side crawler

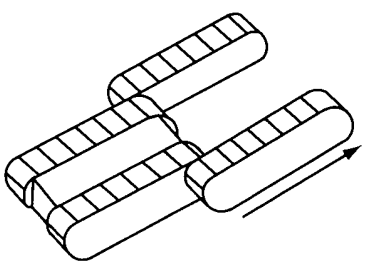

(a) Slide motion

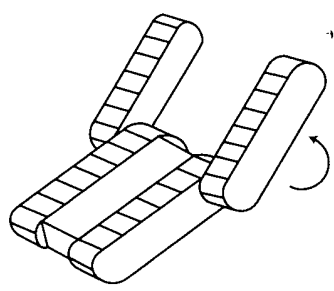

(b) Flip motion
Fig.2 Side crawler motion

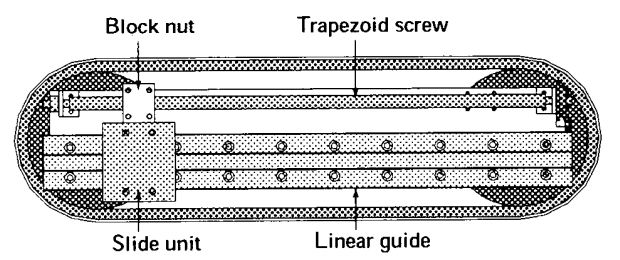

Fig.3 Slide mechanism

\section{3 フリップ機構の設計}

クローラ型レスキューロボットの多くは, フリップ機構を 胴体に取り付けているが, 本レスキューロボットはスライド 機構が胴体側にあるため, フリップ機構を取り付けることが 難しい. そこで本研究では, フリップ機構をサイドクローラ に取り付ける方法を採用した。これにより，サイドクローラ

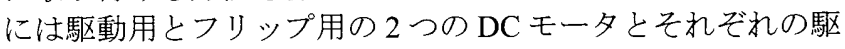
動機構が内蔵されることになり, その結果, サイドクローラ の自重が大きくなってしまう。フリップ機構には, サイドク ローラを任意の姿勢に保持することが求められるが, 自重が 大きくなるため DC モータで姿勢を保持することが難しい. そこで, 機構自身で保持できるようにフリップ機構にウォー ムギヤを用いる．またフリップ角度としては士180[deg]の範 囲で動作するものとする。 


\section{4 ハードゥェア構成}

本レスキューロボットには 8 個の DC モータが使用されて いる. Fig.4 に示すように, サイドクローラとセンタクロー ラの駆動に 4 個, サイドクローラのスライドに 2 個, サイド クローラのフリップに 2 個となっている. すべての DC モー タにはロータリーエンコーダが取り付けられており, 回転数 を計測することで各クローラの回転角速度，サイドクローラ のスライド量とフリップ角度を測定できる. また, 重心が常 にロボット全長の半分の位置にくるように, DC モータをロ ボットの前後左右に均等になるように配置している。これに よりサイドクローラの伸縮によって重心位置が変化しても 転倒せずに安定した走行が可能となる. センタクローラの間 にはスペースを設けており，CCD カメラ，距離センサ，バ ッテリ，電源回路などを組み込むことができる.

\section{5 実機の外観}

Fig.5 と Fig.6 に開発したレスキューロボットを示す. Fig.5 は通常時のサイドクローラを縮めた状態で, 全長が 444[mm], 幅 408[mm], 高さ $125[\mathrm{~mm}]$ である. Fig.6 はサイドクローラ 最大伸張時の状態を示しており, 全長は $763[\mathrm{~mm}]$ である。ま た, 質量は約 $16.0[\mathrm{~kg}]$ となっている. クローラの表面には走 行面とのグリップ力を高めるために, ゴムが取り付けられて いる.

\section{3. 実験}

開発したレスキューロボットの走行実験, 段差の乗り越え 実験の結果を示す。ただし，実験は平坦な路面上で行い，操 縦者は実機を目視しながら操縦を行った。

\section{1 走行実験}

走行実験として通常時とサイドクローラ伸張時の直進走 行実験, 旋回動作実験を行った。直進走行については通常時 と伸張時ともに直進走行することを確認したが，旋回動作に ついては，クローラが滑りを生じながら旋回するため, 摩擦 による抵抗が大きく不安定であった. また各クローラの速度 の違いやサイドクローラのスライドにより回転中心が変化 するため，旋回動作を安定して行うためには，それらの関係 式を導出する必要がある。

\section{2 段差の乗り越え実験}

伸縮駆動機構の性能を確認するために, 高さ $170[\mathrm{~mm}]$ の段 差の乗り越え実験を行った. 以下にその手順, Fig.7にその 様子を示す。

Step 1. Fig.7(a)のようにサイドクローラを縮めた状態で乗り 越えられない段差に遭遇したら, サイドクローラをス ライドさせる $($ Fig.7(b))。ここでは，スライド機構の 最大伸張位置まで伸价ている.

Step 2. Fig.7(c)のようにサイドクローラをフリップさせ，そ の状態のまま前進し, 段差にサイドクローラを引っ掛 ける.

Step 3. サイドクローラを Step 2 と逆方向にフリップさせ, セ ンタクローラを持ち上げ（Fig.7(d)），サイドクローラ 全体が段差に乗り上げるまで前進する（Fig.7(e)）.

Step 4. サイドクローラが後退しないようにスライド機構で センタクローラをスライドさせる（Fig.7(f)）。

\section{4. おわりに}

本研究では, 狭隘環境内での作業を可能にするレスキュー ロボットの開発を目的として, サイドクローラが伸縮可能な レスキューロボットを開発し, 走行実験および段差の乗り越 え実験を行った. 今後の課題としては，旋回動作を制御する ための操縦法の提案, 遠隔操作システムの構築, 瓦䃇環境で の実証実験が挙げられる。

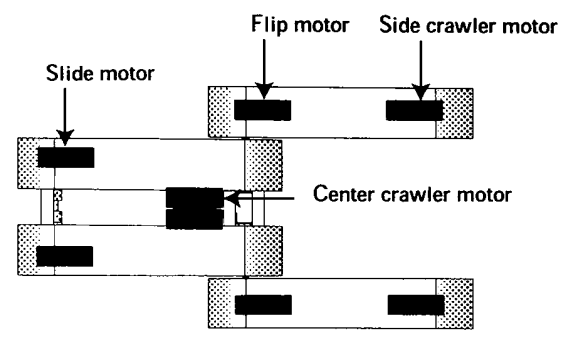

Fig.4 Motors location

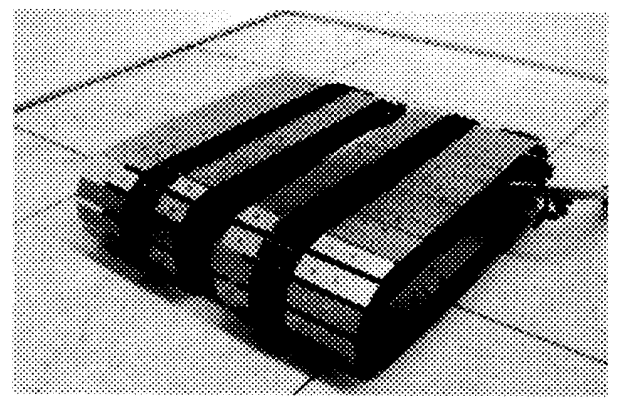

Fig.5 Over view of rescue robot in drive mode

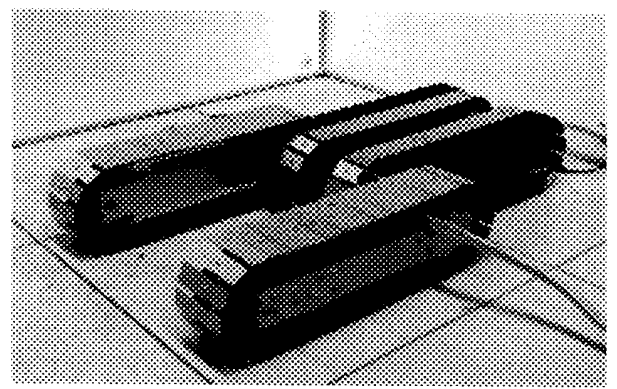

Fig.6 Over view of rescue robot in expansion mode

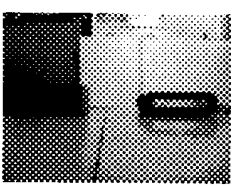

(a)

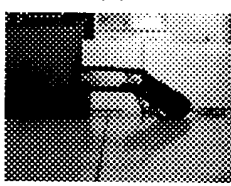

(d)

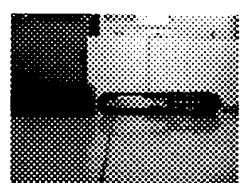

(b)

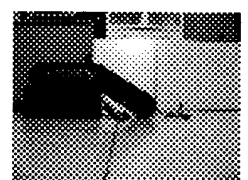

(e)

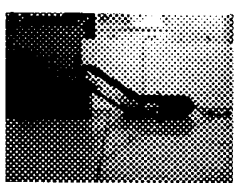

(c)

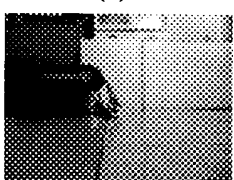

(f)
Fig.7 Experiment of climbing motion

\section{参考文献}

[1] 森淳，山田浩也，広瀬茂男：“三次元索状能動体 ACM-R3 の設計 開発とその基本操舵制御”, 日本ロボット学会誌, vol.23, no.7, pp. 120-131, 2005

[2] 亀川哲志, 松野文俊 : “遠隔操作性を考慮した双頭へビ型レスキ ューロボット KOHGA の開発”, 日本ロボット学会誌, vol.25, no.7, pp.52-59, 2007 